Research Article

\title{
Varietal evaluation of promising maize genotypes in mid hills of Nepal
}

\author{
Bipin Neupane ${ }^{1 *}$, Ankur Poudel ${ }^{1}$ and Pradeep Wagle ${ }^{2}$ \\ ${ }^{1}$ Institute of Agriculture and Animal Science, Lamjung Campus, Nepal \\ ${ }^{2}$ USDA, Agricultural Research Service, Grazinglands Research Laboratory, El Reno, OK, USA \\ *Correspondence: neupanebpn63@gmail.com \\ *ORCID: https://orcid.org/0000-0001-7386-1053 \\ Received: July10, 2020; Accepted: October 10, 2020; Published: October 30, 2020 \\ (C) Copyright: Neupane et al. (2020). \\ (c) (1) (8) \\ International License.
}

\begin{abstract}
The varietal evaluation of hybrid maize (Zea mays L.) genotypes with desired performance is one of the main objectives of maize breeding program. Fourteen hybrid maize genotypes were evaluated for 17 quantitative and nine qualitative traits in randomized complete block design with three replications at Sundarbazar, Lamjung, Nepal during May to September, 2019. The major objective was to identify superior genotypes based on genotypic and phenotypic variability, heritability, genetic advance, and correlation between grain yield and yield associated traits. We observed significant differences for 17 quantitative traits among the tested genotypes. Large variation was observed for grain yield among genotypes. Genotype RL-24-0/ RL-111 had the lowest yield (5.53 mt/ha) and Pioneer had the highest yield $(11.98 \mathrm{mt} / \mathrm{ha})$ whereas check variety Rampur Hybrid-10 yielded of $8.23 \mathrm{mt} / \mathrm{ha}$. Grain yield showed highly significant positive correlations with stem girth $(\mathrm{r}=0.67)$ and number of ears $(\mathrm{r}=0.6)$, but significant negative correlation with anthesis-silking interval $(\mathrm{r}=-0.55)$. The dendrogram grouped 14 genotypes into four clusters. Cluster I incorporated the highest number (five) of genotypes, which also had highest cluster mean (average yield of $\sim 10$ $\mathrm{mt} / \mathrm{ha}$ ) for grain yield. Traits namely test weight, ear aspect, anthesis-silking interval, number of ears, and tassel branching had high genotypic and phenotypic coefficient of variations, and heritability along with high genetic advances, indicating that these traits can be considered for maize breeding program.
\end{abstract}

Keywords: Cluster, GCV, Genetic advance, Heritability, Hybrid, PCV

Correct citation: Neupane, B., Poudel, A., \& Wagle, P. (2020). Varietal evaluation of promising maize genotypes in mid hills of Nepal. Journal of Agriculture and Natural Resources, 3(2), 127-139.

DOI: https://doi.org/10.3126/janr.v3i2.32491

\section{INTRODUCTION}

Maize (Zea mays L.) is one of the World's leading crops cultivated in tropics, sub-tropics, and temperate regions. It was domesticated around 7000 years ago in Central Mexico. Maize belongs to family Poaceae and tribe Maydae with the chromosome number $2 n=20$. It has the highest yield potential over other cereals and is therefore known as 'the queen of cereals' (Singh, 2002). It is the only crop adaptable to different agro-ecological zones due to its large diversity (Ferdu et al., 2002). In Nepal, maize is the second most important cereal crops in terms of area and production after paddy rice (Oryza sativa L.) (Adhikari, 2007; MoALD, 2020). It is grown in an area of 956, 
Journal of Agriculture and Natural Resources (2020) 3(2): 127-139

ISSN: 2661-6270 (Print), ISSN: 2661-6289 (Online)

DOI: https://doi.org/10.3126/janr.v3i2.32491

447 ha with a total production of $2,713,635$ metric ton $(\mathrm{mt})$ and productivity of $2.84 \mathrm{mt} / \mathrm{ha}$ (MoALD, 2020). In Lamjung district, maize is cultivated in an area of 9,935 ha producing up to 23,943 mt with the productivity of $2.41 \mathrm{mt} / \mathrm{ha}$ (MoALD, 2020).

The hybrid maize of multinational seed companies is progressively being popular among farmers in Nepal (Tripathi et al., 2016). Although few hybrids are developed from national research system of Nepal, they are not competitive with hybrids of multinational seed companies (Tripathi et al., 2016). Large numbers of multinational companies' hybrids have been registered in National Seed Board of Nepal. The commercial seed companies are the main source of seed as the acreage of hybrid maize has expanded extensively in Terai (i.e., plain area) and partly in mid hill of Nepal. Farmers and breeders need to select suitable maize hybrids with high yield and other essential agronomic characteristics. Most of the released maize varieties in Nepal are trialed at research stations only, lacking field evaluations most likely due to lack of proper extension service. Even some released varieties are not accepted by farmers due to lower than expected levels of production at the farmer's fields (Gurung et al., 2011). Consequently, there is dominance of the multinational varieties over locally released varieties on the market (Gurung et al., 2011).

Hybrid maize seed marketing is flourishing every year. However limited commercial hybrids are suitable for cultivation due to the country's diverse agro ecological regions. Therefore, it is necessary to identify superior maize hybrids that are suitable for different agro-ecological regions. A previous study assessed 117 maize hybrids of 20 seed companies for grain yield and other traits at three sites (eastern, central, and inner Terai of Nepal) in winter season of 2011 and 2012 to identify superior maize hybrids suitable for winter time planting in those regions (Tripathi et al., 2016). To our knowledge, extensive evaluation of several maize varieties from different seed companies is lacking for mid hills of Nepal. Thus, this study was undertaken to compare germplasms of locally released and multinational maize varieties under field conditions in mid hill of Nepal. Such type of evaluation of germplasms is useful to produce improved maize varieties.

\section{MATERIALS AND METHODS}

\section{Experimental site}

This experiment was carried out at Sundarbazar, Lamjung, Nepal during a growing season from May to September, 2019. The experiment site was located at latitude of $28.1448^{\circ} \mathrm{N}$, longitude of $84.4120^{\circ} \mathrm{E}$, and altitude of $610 \mathrm{~m}$. It was situated in the sub-tropical climatic zone of Nepal with an annual average rainfall of $203 \mathrm{~mm}$. Total rainfall of $1040 \mathrm{~mm}$ was recorded during the growing season (May to September, 2019). The $\mathrm{P}^{\mathrm{H}}$ of experimental site was slightly acidic and the texture of the soil was silt loam.

\section{Experimental materials}

Fourteen hybrid maize genotypes namely Rampur Hybrid-4, Rampur Hybrid-6, Rampur Hybrid10 (Standard check), Pariposa 4525, Ganga Kaberi, Pioneer, Rashi 3022, RL-24-8/RML-25, RL213/RML-17, RL-24-0/RL-111, RML-95/RML-96, RML-86/RML-96, RML-11-2/RML-18 and RL-35-1/RL-105 were used in the experiment. Four multinational varieties (Pariposa 4525, Ganga Kaberi, Pioneer, and Rashi 3022) were received from local market. Except multinational varieties, all ten genotypes were received from National Maize Research Program, Rampur, Chitwan, Nepal. 
Journal of Agriculture and Natural Resources (2020) 3(2): 127-139

ISSN: 2661-6270 (Print), ISSN: 2661-6289 (Online)

DOI: https://doi.org/10.3126/janr.v3i2.32491

\section{Experimental design and crop management}

The experiment was conducted in randomized complete block design (RCBD) with three replications. Each experiment plots were of size $10 \mathrm{~m}^{2}(5 \mathrm{~m} \times 2 \mathrm{~m})$. The seeds were sown using crop geometry of $75 \mathrm{~cm} \times 25 \mathrm{~cm}$ (row to row $\times$ plant to plant). Fertilizer was applied at the rate of 120:60:40 NPK kg/ha. Nitrogen was applied in two splits (half/half) at knee-high and pretasseling/silking stages. Earthing up was done at knee high stage.

\section{Data collection}

Observations on yield and yield components included plant height $(\mathrm{cm})$, number of ears per plant, ear height $(\mathrm{cm})$, ear length $(\mathrm{cm})$, ear girth $(\mathrm{cm})$, number of kernels row per ear, number of kernels per row, days to $50 \%$ tasseling, days to $50 \%$ silking, anthesis-silking interval, stem girth $(\mathrm{cm})$, tassel branching, ear aspect, germination percentage (\%), 1000 grain weight (gm) and grain yield (mt/ha). Grain yield was calculated using equation 1 as adopted by Carangal et al., (1971) and Shrestha et al., (2018) by adjusting the grain moisture at $15 \%$ and converted to the grain yield per hectare basis. Qualitative observations included tassel-glume base color, silk color at emergence, pubescence, leaf color, leaf orientation, leaf width, kernel row arrangement, husk cover and grain texture. Data were obtained on randomly selected 10 plants from each experimental plot for all the traits under consideration except for 50\% tasseling, 50\% silking and anthesis-silking interval. Standard staging system was used during the test period to identify the development stages of maize varieties, and a stage was characterized when $50 \%$ of plant population reached the corresponding stage.

Grain yield $\left(\frac{\mathrm{kg}}{\mathrm{ha}}\right)=\frac{\mathrm{FWT}\left(\frac{\mathrm{kg}}{\mathrm{plot}}\right) \times(100-\mathrm{HMP}) \times \mathrm{SCF} \times 10000}{(100-\mathrm{DMP}) \times \mathrm{NPA}}$

Where,

FWT $=$ Fresh weight of ear in kg per plot at harvest

$\mathrm{HMP}=$ Grain moisture percentage at harvest

DMP $=$ Desired moisture percentage, i.e. $15 \%$

$\mathrm{NPA}=$ Net harvest plot area, $\mathrm{m}^{2}$

$\mathrm{SCF}=$ Shelling coefficient, i.e. 0.8

\section{Statistical analysis}

The R Studio, SPSS version 25 and Minitab were used for statistical analyses. Data were assigned to analysis of variance (ANOVA) considering genotypes as fixed effects and replications as random effects. The phenotypic coefficient of variation (PCV) and genotypic coefficient of variation $(\mathrm{GCV})$ were estimated according to the procedure outlined by Chaudhary and Prasad (1968). The GCV and PCV were categorized as low if less than 10\%, moderate if 10-20\%, and high if $\geq 20 \%$ as presented by Sivasubramanian and Menon, (1973). Heritability percentage was categorized as low if less than $20 \%$, medium if $20 \%-40 \%$, and high if $\geq 40 \%$ as indicated by Adhikari et al. (2018). Genetic advance (GA) and genetic advance as percent of mean (GAM) were determined by using equations 2 and 3, as in Johnson et al. (1955) and Falconer (1996). Correlation coefficient between two characters was calculated by using components of variance and covariance as in Weber \& Moorthy, (1952). Cluster analysis among genotypes was performed by complete linkage (farthest-neighbor) method under Euclidean distance. Qualitative observations were evaluated following the guidelines provided by CIMMYT, Mexico. 
Genetic Advances $(\mathrm{GA})=\mathrm{k} . \sigma \mathrm{p} . \mathrm{H}$

Where,

$\mathrm{k}=$ selection differential constant $(\mathrm{k}=2.056$ at $5 \%$ selection intensity $)$

$\sigma \mathrm{p}=$ phenotypic standard deviation

$\mathrm{H}=$ broad sense heritability

Genetic advances as per mean $(\mathrm{GAM})=\frac{G A}{X} \times 100$

Where,

$\mathrm{GA}=$ genetic advances under selection

$\mathrm{X}=$ population mean in which selection will be employed

\section{RESULTS AND DISCUSSION}

\section{Comparison of maize genotypes for traits}

The analysis of variance revealed the existence of significant differences among genotypes for all the traits, indicating the presence of considerable genetic variability among tested genotypes (Table 1). Large differences among genotypes indicate the potential for improving different quantitative and qualitative characters via selection. Similar to our current findings, (Ogunniyan \& Olakojo, 2014) reported significant genotypic differences for plant height, ear height, days to $50 \%$ tasseling and silking, anthesis-silking interval (ASI), number of leaves per plant, number of ears per plant, 1000 grain weight and so on in inbred lines of maize in Nigeria.

\section{Table 1. Analysis of variance for 17 traits in hybrid maize.}

\begin{tabular}{|c|c|c|c|c|}
\hline \multirow[t]{2}{*}{ SN } & \multirow[t]{2}{*}{ Traits } & \multicolumn{3}{|c|}{ Mean sum of squares } \\
\hline & & $\begin{array}{l}\text { Replications } \\
\text { (D.F. =2) }\end{array}$ & $\begin{array}{l}\text { Treatments } \\
\text { (D.F. }=13 \text { ) }\end{array}$ & $\begin{array}{l}\text { Error } \\
\text { (D.F. =26) }\end{array}$ \\
\hline 1. & Days to $50 \%$ Tasseling & 0.67 & $21.97 * * *$ & 1.58 \\
\hline 2. & Days to $50 \%$ Silking & 1.50 & $23.69 * * *$ & 1.96 \\
\hline 3. & Anthesis-Silking Interval & 0.30 & $2.44 *$ & 0.92 \\
\hline 4. & Plant Height $(\mathrm{cm})$ & 7.55 & $774.60 * * *$ & 3.67 \\
\hline 5. & Number of Ears Per Plant & 0.46 & $0.44 * * *$ & 0.07 \\
\hline 6. & Ear Height $(\mathrm{cm})$ & 176.32 & $493.96 * * *$ & 91.13 \\
\hline 7. & Ear Length $(\mathrm{cm})$ & 4.71 & $9.04 * * *$ & 0.90 \\
\hline 8. & Ear Girth $(\mathrm{cm})$ & 0.35 & $2.15^{* * *}$ & 0.27 \\
\hline 9. & Number of Kernels Row Per Ear & 0.14 & $6.11 * * *$ & 0.31 \\
\hline 10. & Number of Kernels Per Row & 2.78 & $23.97 * * *$ & 4.24 \\
\hline 11. & Number of leaves & 1.64 & $2.19 * *$ & 0.73 \\
\hline 12. & Stem Girth $(\mathrm{cm})$ & 0.59 & $0.64 * *$ & 0.17 \\
\hline 13. & Tassel Branching & 7.88 & $35.46 * * *$ & 3.10 \\
\hline 14. & Ear Aspect & 0.51 & $1.37 *$ & 0.49 \\
\hline 15. & Germination Percentage (\%) & 85.71 & $64.45^{*}$ & 27.42 \\
\hline 16. & 1000 Grain Weight (gm) & 182.2 & $6994.1 * * *$ & 212.00 \\
\hline 17. & Grain Yield (t/ha) & 6.14 & $9.01 * * *$ & 0.42 \\
\hline
\end{tabular}

*Significant at 5 percent level, ** significant at 1 percent level and *** significant at 0.1 percent level.

\section{Genotypic and phenotypic coefficient of variations}

The estimation of GCV was high for ear aspect (21.25), ASI (20.60) and tassel branching (20.03). This result was in agreement with previous studies for tassel branching in hybrid maize in Iran (Majid, 2011) and for ASI in inbred maize lines in India (Arunkumar et al., 2015). The estimation 
Journal of Agriculture and Natural Resources (2020) 3(2): 127-139

ISSN: 2661-6270 (Print), ISSN: 2661-6289 (Online)

DOI: https://doi.org/10.3126/janr.v3i2.32491

of PCV was high for ear aspect (34.79), ASI (34.64), number of ears per plant (25.02), tassel branching (22.73) and grain yield (20.26). Several previous studies had also recorded similar results for grain yields in maize (Ghimire and Timsina, 2014; Taye, 2014 and Abirami et al., 2005). Similar result were recorded for ASI (Arunkumar et al., 2015) and tassel branching in inbred maize line in Ethiopia (Taye, 2014). High PCV and GCV shows that there is a probability of improving traits through selection process. Likewise, PCV values were higher than their counterpart GCV values for all the characters considered (Table 2). The results were consistent with those obtained by single cross hybrid protein maize in Nigeria (Yusuf, 2010).

The differences between GCV and PCV were small for days to 50\% tasseling, days to 50\% silking, and plant height, indicating that the environmental effect on the expression of those traits is lower and selection based on these traits will be effective for considerable genetic improvement. Large differences between GCV and PCV for ear aspect, ASI, and number of ears per plant indicates selection based on phenotypic performance will be ineffective for considerable genetic improvement. Similar results were reported for days to $50 \%$ silking, days to $50 \%$ tasseling and ear aspect in hybrid maize in India (Manjunatha et al., 2018).

\section{Heritability}

The heritability in broad sense estimate varied from 0.31 for germination percentage to 0.98 for plant height (Table 2). Plant height (0.98), 1000 grain weight (0.91), grain yield (0.87), number of kernel rows (0.85), days to $50 \%$ tasseling (0.81), days to $50 \%$ silking (0.78), tassel branching (0.77), ear length (0.74), ear girth (0.69), number of ear per plant $(0.61)$, number of kernels per row (0.60), ear height (0.59) and stem girth (0.46) were high heritable traits. This indicates that the traits under study are less affected in their expression by the environment. Similar results were reported for grain yield and ear length in inbred maize in India (Nadagoud, 2008). Similar results were reported for ear height and plant height (Vashistha, 2013; Nadagoud, 2008 and Taye, 2014), and for days to $50 \%$ tasseling, days to $50 \%$ silking and number of kernels per row in maize (Nadagoud, 2008 and Taye, 2014). Similar results were also reported for tassel branch and number of kernel row per ear (Taye, 2014), 1000 grain weight (Bartaula et al., 2019), and ear girth in monsoon season in Telengana, India (Sridhar, 2017), and stem girth in maize in Ludhiana, India (Kapoor and Batra, 2015). Number of leaves (0.39), ear aspect (0.37), ASI (0.35), and germination percentage (0.31) were moderately heritable traits, while there were no any low heritable traits. Similar result for ASI was recorded in maize genotypes in Allahabad, India (Vashistha, 2013). The influence of environment on the phenotypic nature of traits can be lead to moderate heritability estimates.

\section{Genetic advance and genetic advance as percent of mean}

The GAM was the highest for grain yield (36.38) followed by tassel branching (36.37), 1000 grain weight (34.55), number of ears per plant (31.97), ear aspect (26.75), and ASI (25.21). The GAM was moderate for number of kernel rows (17.79), ear height (17.12), ear length (14.06), plant height (11.84), and number of kernels per row (11.50). Low magnitude of GAM was observed for ear girth (8.85), days to $50 \%$ tasseling (8.11), days to 50\% silking (7.80), stem girth (7.33), number of leaves (6.57) and germination percentage (4.58) (Table 2). The results indicate control of nonadditive gene action on these traits, suggesting that heterosis breeding will be useful (i.e. the pure lines with these traits can be used for crop improvement). Similar results were presented for maize 
inbred lines in Ethiopia for tassel branching, grain yield and 1000 grain weight (Taye, 2014) and days to 50\% silking (Tadesse et al., 2018). Number of leaves, ear length, and ASI have also shown similar results in maize during summer season in Dang, Nepal (Bartaula et al., 2019).

Heritability estimates alone is not suitable as high heritability along with high GAM would be more effective. High heritability coupled with high GAM was observed for grain yield, tassel branching, 1000 grain weight, and number of ears per plant, indicating the control of additive gene of action and a greater scope for selection of these traits. Similar findings were recorded for grain yield in India (Freeman et al., 2019) and 1000 grain weight for maize in Bangladesh (Rahman et al., 2018).

Table 2. Estimation of genetic parameters for 17 traits in hybrid maize.

\begin{tabular}{|c|c|c|c|c|c|c|}
\hline $\mathrm{SN}$ & Traits & $\begin{array}{c}\mathrm{PCV} \\
\%\end{array}$ & $\begin{array}{c}\mathrm{GCV} \\
\%\end{array}$ & $\begin{array}{c}\text { Heritability } \\
\left(\mathrm{h}^{2}{ }_{\mathrm{bs}}\right)\end{array}$ & GA & GAM \\
\hline 1. & Days to $50 \%$ Tasseling & 4.86 & 4.37 & 0.81 & 4.83 & 8.11 \\
\hline 2. & Days to $50 \%$ Silking & 4.81 & 4.27 & 0.78 & 4.91 & 7.80 \\
\hline 3. & Anthesis-Silking Interval & 34.64 & 20.59 & 0.35 & 0.87 & 25.21 \\
\hline 4. & Plant Height $(\mathrm{cm})$ & 5.83 & 5.78 & 0.98 & 32.78 & 11.84 \\
\hline 5. & Number of Ear Per Plant & 25.05 & 19.71 & 0.61 & 0.56 & 31.97 \\
\hline 6. & Ear Height $(\mathrm{cm})$ & 13.95 & 10.77 & 0.59 & 18.42 & 17.79 \\
\hline 7. & Ear Length $(\mathrm{cm})$ & 9.11 & 7.88 & 0.74 & 2.93 & 14.06 \\
\hline 8. & Ear Girth $(\mathrm{cm})$ & 6.14 & 5.14 & 0.69 & 1.36 & 8.85 \\
\hline 9. & Number of Kernels Row Per Ear & 10.05 & 9.32 & 0.85 & 2.65 & 17.79 \\
\hline 10. & Number of Kernels Per Row & 9.19 & 7.16 & 0.60 & 4.11 & 11.50 \\
\hline 11. & Number of leaves & 8.07 & 5.07 & 0.39 & 0.90 & 6.57 \\
\hline 12. & Stem Girth $(\mathrm{cm})$ & 7.60 & 5.20 & 0.46 & 0.55 & 7.33 \\
\hline 13. & Tassel Branching & 22.73 & 20.03 & 0.77 & 5.96 & 36.37 \\
\hline 14. & Ear Aspect & 34.79 & 21.25 & 0.37 & 0.68 & 26.75 \\
\hline 15. & Germination Percentage (\%) & 7.16 & 3.99 & 0.31 & 4.03 & 4.58 \\
\hline 16. & 1000 Grain Weight (gm) & 18.34 & 17.54 & 0.91 & 93.65 & 34.55 \\
\hline 17. & Grain Yield (t/ha) & 20.26 & 18.91 & 0.87 & 3.25 & 36.38 \\
\hline
\end{tabular}

\section{Correlation}

Correlation studies showed that stem circumference $(r=0.67)$ and number of ears per plant $(r=0.59)$ had positive and significant relationship with grain yield. This result signifies that selection of these traits would directly affect the expression of grain yield facilitating the selection and progress on breeding program. The ASI showed highly significant negative correlation $(\mathrm{r}=-0.58)$ with grain yield. Correlations of grain yield with other traits were not significant (Table 3). Similar results were reported earlier in maize by several studies for different characters viz., for number of ear per plant (Taye, 2014) and ASI (Bartaula et al., 2019) 
Journal of Agriculture and Natural Resources (2020) 3(2): 127-139

ISSN: 2661-6270 (Print), ISSN: 2661-6289 (Online) DOI: https://doi.org/10.3126/janr.v3i2.32491

\section{Table 3. Correlation of 17 traits in hybrid maize.}

\begin{tabular}{|c|c|c|c|c|c|c|c|c|c|c|c|c|c|c|c|c|}
\hline & $\mathrm{EL}$ & EA & $\mathrm{EH}$ & EPP & NKPR & $\mathrm{NL}$ & NKR & $\mathrm{PH}$ & $\mathrm{SG}$ & TB & TGW & DTT & DTS & ASI & GP & GY \\
\hline EG & $0.38 *$ & 0.01 & 0.11 & -0.27 & 0.19 & 0.01 & 0.04 & 0.12 & -0.04 & -0.05 & 0.19 & -0.22 & -0.17 & 0.08 & 0.01 & 0.09 \\
\hline EL & & 0.07 & 0.20 & -0.17 & $0.67 * *$ & $0.44 * *$ & $0.35^{*}$ & 0.01 & -0.04 & 0.14 & -0.27 & -0.05 & 0.05 & 0.27 & -0.02 & -0.11 \\
\hline EA & & & -0.19 & 0.13 & -0.06 & 0.01 & $0.39 *$ & 0.18 & 0.16 & -0.07 & -0.23 & 0.11 & -0.02 & $-0.35^{*}$ & -0.26 & 0.15 \\
\hline $\mathrm{EH}$ & & & & -0.09 & -0.08 & $0.40^{* *}$ & -0.04 & $0.42 * *$ & -0.13 & -0.15 & -0.05 & 0.10 & 0.21 & $0.31 *$ & -0.19 & -0.07 \\
\hline EPP & & & & & 0.01 & 0.12 & -0.05 & 0.25 & $0.54 * *$ & 0.07 & -0.23 & $-0.38 *$ & $-0.50 * *$ & $-0.33^{*}$ & -0.25 & $0.6 * *$ \\
\hline NKPR & & & & & & $0.31 *$ & $0.38^{*}$ & -0.13 & 0.21 & 0.06 & $-0.36^{*}$ & -0.23 & -0.15 & 0.17 & 0.08 & 0.08 \\
\hline $\mathrm{NL}$ & & & & & & & $0.35 *$ & 0.18 & 0.16 & 0.00 & -0.18 & -0.01 & 0.07 & 0.21 & -0.19 & 0.03 \\
\hline NKR & & & & & & & & -0.28 & 0.18 & 0.17 & $-0.46 * *$ & $0.35^{*}$ & $0.32 *$ & -0.04 & -0.05 & 0.07 \\
\hline $\mathrm{PH}$ & & & & & & & & & 0.08 & -0.12 & -0.13 & $-0.33^{*}$ & -0.26 & 0.13 & -0.29 & 0.03 \\
\hline SG & & & & & & & & & & 0.05 & 0.03 & -0.05 & -0.19 & $-0.34 *$ & -0.13 & $0.67 * *$ \\
\hline $\mathrm{TB}$ & & & & & & & & & & & -0.21 & -0.13 & -0.17 & -0.10 & -0.09 & -0.07 \\
\hline TSW & & & & & & & & & & & & $0.32 *$ & 0.25 & -0.13 & -0.04 & 0.17 \\
\hline DTT & & & & & & & & & & & & & $0.92 * *$ & -0.08 & -0.10 & -0.04 \\
\hline DTS & & & & & & & & & & & & & & $0.31 *$ & 0.03 & -0.25 \\
\hline ASI & & & & & & & & & & & & & & & 0.30 & $-0.55^{* *}$ \\
\hline GP & & & & & & & & & & & & & & & & -0.29 \\
\hline
\end{tabular}

EG=Ear Girth, EL=Ear Length, EA=Ear Aspect, EH=Ear Height, EPP=Ears per plant, NKPR= Number of kernels per row, NL= Number of leaves, NKR= Number of Kernel rows, PH= Plant Height, SG= Stem Girth, TB= Tassel Branching, TGW= Thousand Grain Weight, DTT= Days to Tasseling, DTS= Days to Silking, ASI= Anthesis-Silking Interval, GP= Germination Percentage, GY= Grain Yield.*,** significant at 5 percent and 1 percent respectively. 
Journal of Agriculture and Natural Resources (2020) 3(2): 127-139

ISSN: 2661-6270 (Print), ISSN: 2661-6289 (Online)

DOI: https://doi.org/10.3126/janr.v3i2.32491

\section{Cluster analysis}

Among 14 hybrid maize genotypes, cluster analysis grouped into four clusters following complete linkage method. Maximum genotypes (five) were aggregated in cluster I, while minimum genotypes (two) were aggregated in cluster IV. Cluster II and III comprised three and four genotypes, respectively (Table 4). In consideration in improvement of various traits, mean value of 17 different traits were calculated. Mean performance for these traits showed that cluster I had maximum grain yield and, number of ears, and minimum days to tasseling and silking. The cluster II was characterized with maximum ear circumference and ear height. The cluster III was grouped with maximum 1000 grain weight and, stem circumference, and minimum ASI. Similarly, the cluster IV was characterized with maximum germination percentage, tassel branching, no of kernels per row, no of kernel rows, ear length, and, ear aspect, number of leaves and minimum plant height (Table 5).

Table 4. Grouping of 14 hybrid maize genotypes into four clusters.

\begin{tabular}{lcl}
\hline Cluster & Number of genotypes & Name of genotypes \\
\hline I & 5 & Pariposa 4525, Ganga Kaberi, Pioneer, RL-24-8/RML-25, RL- \\
& & 213/RML-17 \\
II & 4 & RML-95/RML-96, Rampur Hybrid-4, Rampur Hybrid-6, RML- \\
& & 86/RML-96 \\
III & 3 & RL-24-0/RL-111, Rampur Hybrid-10, Rashi 3022 \\
IV & 2 & RML-11-2/RML-18, RL-35-1/RL-105 \\
\hline
\end{tabular}

Table 5. Cluster mean for 17 traits in hybrid maize.

\begin{tabular}{llcccc}
\hline SN & \multicolumn{1}{c}{ Traits } & Cluster Means & \\
\hline & & Cluster-I & Cluster-II & Cluster-III & Cluster-IV \\
\hline 1. & Days to 50\% Tasseling & 56.80 & 62.33 & 59.00 & 61.67 \\
2. & Days to 50\% Silking & 59.73 & 65.25 & 63.67 & 65.67 \\
3. & Anthesis-Silking Interval & 2.93 & 2.91 & 4.67 & 4.00 \\
4. & Plant Height (cm) & 282.98 & 274.16 & 282.44 & 258.73 \\
5. & Number of Ear Per Plant & 2.13 & 1.82 & 1.37 & 1.38 \\
6. & Ear Height (cm) & 105.34 & 108.29 & 116.63 & 98.00 \\
7. & Ear Length (cm) & 20.93 & 19.20 & 21.61 & 22.95 \\
8. & Ear Girth (cm) & 15.55 & 15.04 & 16.17 & 14.63 \\
9. & Number of Kernels Row Per Ear & 14.48 & 15.15 & 14.16 & 16.68 \\
10. & Number of Kernels Per Row & 36.86 & 33.13 & 35.06 & 39.41 \\
11. & Number of leaves & 13.57 & 13.50 & 14.01 & 14.01 \\
12. & Stem Girth (cm) & 7.81 & 7.87 & 7.13 & 7.30 \\
13. & Tassel Branching & 17.14 & 16.22 & 14.87 & 17.15 \\
14. & Ear Aspect & 2.67 & 2.70 & 1.93 & 2.86 \\
15. & Germination Percentage (\%) & 87.14 & 86.45 & 89.08 & 91.96 \\
16. & 1000 Grain Weight (gm) & 248.93 & 301.05 & 297.43 & 226.67 \\
17. & Grain Yield (t/ha) & 10.01 & 9.72 & 7.24 & 7.24 \\
\hline
\end{tabular}




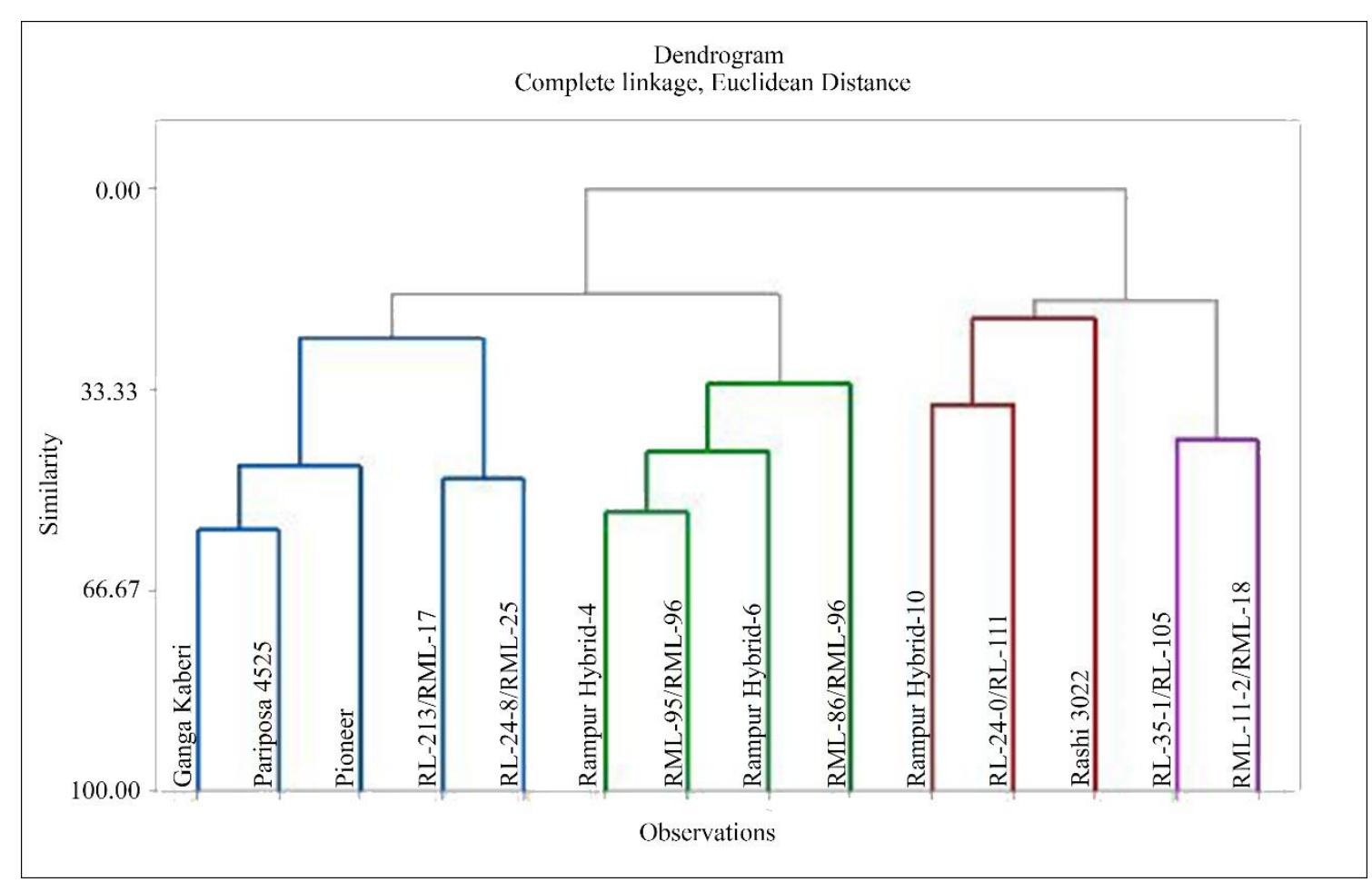

\section{Figure 1: Dendrogram of 14 hybrid maize genotypes for quantitative traits.}

\section{Qualitative traits}

Graphical representation showing the frequencies of the qualitative traits for maize genotypes studied are presented in Table 6.

Tassel-glume base color- Out of fourteen maize genotypes studied, ten genotypes (71\%) had glume base color, indicating glume base color at tassel might be linked to high yielding or yield attributing traits.

Silk color at emergence- Thirteen genotypes (93\%) out of fourteen had pink silk color whereas only one genotype (7\%) had green silk color at emergence. It indicates that the pink silk color determining gene might be linked to high grain yielding genes.

Pubescence- All fourteen genotypes (100\%) had pubescence in their leaf suggesting that presence of pubescence might have some effect in the yield improvement.

Leaf color- Light green color was expressed in two genotypes (14\%), green in nine genotypes $(64 \%)$, and dark green in three genotypes $(22 \%)$. The results indicate that suggesting medium green leaf color might be favorable with respect to grain yield improvement.

Leaf orientation- Nine genotypes (64\%) had erect leaf orientation whereas five genotypes $(36 \%)$ had drooping leaf orientation. It shows that erect leaf orientation may be the primary interest of breeders for selection to maximize photosynthesis and yield.

Leaf width- Two genotypes (14\%) had narrow, five genotypes (36\%) had medium, and seven genotypes $(50 \%)$ had broad leaf width. The results indicate that leaf width may have some roles in yield.

Kernel row arrangement- All fourteen genotypes (100\%) were having regular kernel row arrangement, indicating common interest of breeders. 
Journal of Agriculture and Natural Resources (2020) 3(2): 127-139

ISSN: 2661-6270 (Print), ISSN: 2661-6289 (Online)

DOI: https://doi.org/10.3126/janr.v3i2.32491

Husk cover- Ten out of fourteen genotypes $(71 \%)$ had good husk cover whereas four genotypes (29\%) had poor husk cover. Breeders might have selected genotypes which were high yielding.

Grain texture- Round grain texture was expressed in eight genotypes (57\%) and flat texture in six genotypes (43\%), indicating a mixed results of grain texture to grain yield.

Table 6: Observation of the qualitative traits in maize genotypes.

\begin{tabular}{|c|c|c|c|c|c|c|c|c|c|}
\hline Maize Genotypes & TGBC & SCE & LP & LC & LO & LW & KRA & $\mathrm{HC}$ & GT \\
\hline Rampur Hybrid-4 & Pink & Pink & Present & Green & Erect & Medium & Regular & Good & Round \\
\hline Rampur Hybrid-6 & Green & Pink & Present & Green & Erect & Medium & Regular & Good & Flat \\
\hline $\begin{array}{l}\text { Rampur Hybrid- } \\
10\end{array}$ & Pink & Pink & Present & $\begin{array}{l}\text { Dark } \\
\text { Green }\end{array}$ & Erect & Medium & Regular & Good & Round \\
\hline RML-86/ RML-96 & Green & Pink & Present & $\begin{array}{l}\text { Light } \\
\text { Green }\end{array}$ & Droop & Broad & Regular & $\mathrm{Bad}$ & Round \\
\hline RML-95/ RML-96 & Pink & Pink & Present & Green & Droop & Broad & Regular & Good & Round \\
\hline $\begin{array}{l}\text { RML-11-2/ RML- } \\
18\end{array}$ & Pink & Pink & Present & $\begin{array}{l}\text { Light } \\
\text { Green }\end{array}$ & Erect & Broad & Regular & Bad & Flat \\
\hline RL-24-0/RL-111 & Green & Pink & Present & Green & Erect & Medium & Regular & Good & Round \\
\hline RL-213/RML-17 & Pink & Pink & Present & Green & Droop & Broad & Regular & Good & Round \\
\hline RL-24-8/RML-25 & Pink & Pink & Present & $\begin{array}{l}\text { Dark } \\
\text { Green }\end{array}$ & Droop & Broad & Regular & Good & Flat \\
\hline RL-35-1/RL-105 & Pink & Pink & Present & Green & Droop & Narrow & Regular & Good & Flat \\
\hline Ganga Kaberi & Pink & Pink & Present & Green & Erect & Medium & Regular & Good & Flat \\
\hline Pioneer & Green & Green & Present & Green & Erect & Broad & Regular & $\mathrm{Bad}$ & Flat \\
\hline Pariposa 4525 & Pink & Pink & Present & $\begin{array}{l}\text { Dark } \\
\text { Green }\end{array}$ & Erect & Broad & Regular & Bad & Flat \\
\hline Rashi 3022 & Pink & Pink & Present & Green & Erect & Narrow & Regular & Good & Flat \\
\hline
\end{tabular}

$T G B C=$ Tassel glume base color,$S C E=$ Silk color at emergence, $L P=$ Leaf pubescence, $L C=$ Leaf color, $L O=$ Leaf orientation, $L W=$ Leaf width, KRA = Kernel row arrangement, $H C=$ Husk cover, and GT=Grain texture.

\section{CONCLUSION}

The present study revealed presence of considerable amount of genetic variability among tested 14 maize genotypes. Phenotypic coefficient of variation (PCV) was higher than genotypic coefficient of variation (GCV) in all traits, indicating low influence of the environment. Traits having high GCV, PCV, heritability along with high genetic advance as percentage of mean (GAM) suggested prevalence of sufficient variability that offered scope of selection. Correlation studies showed that selection of traits (number of ears per plant and stem girth) would directly affect the expression of grain yield facilitating the selection and progress on breeding program. The dendrogram grouped 14 genotypes into four clusters. Cluster I incorporated the highest number (five) of genotypes, which also had highest cluster mean (average yield of $\sim 10 \mathrm{mt} / \mathrm{ha}$ ) for grain yield. Considering grain yield to be the most important trait for evaluating maize hybrids, genotypes under cluster I (Pariposa 4525, Ganga Kaberi, Pioneer, RL-24-8/RML-25 and RL-213/RML-17) looked more promising for mid-hills of 
Journal of Agriculture and Natural Resources (2020) 3(2): 127-139

ISSN: 2661-6270 (Print), ISSN: 2661-6289 (Online)

DOI: https://doi.org/10.3126/janr.v3i2.32491

Nepal. In general, the results indicate that multinational varieties have greater adaptability than locally released hybrid varieties. The existence of large genetic variability among maize genotypes offer tremendous opportunity for future maize breeding program.

\section{ACKNOWLEDGEMENT}

The authors are grateful to Institute of Agriculture and Animal Science, Lamjung campus, Tribhuvan University, Nepal for providing research support and facilities for conducting this experiment. Our sincere acknowledgement goes to Association of Nepalese Agricultural Professional of Americas (NAPA) for funding (NAPA RMG 2019-112) and National Maize Research Program (NMRP), Rampur, Chitwan for providing genetic materials for the experiment.

\section{Authors' contributions}

B. Neupane: Designed \& conducted experiment, data collection \& analysis, and manuscript writing

A. Poudel: Designed experiment, and data analysis

P. Wagle: Data analysis, and manuscript writing

\section{Conflict of interests}

The author declares that there are no conflicts of interests regarding the publication of this paper.

\section{REFERENCES}

Abirami, S., Vanniarajan, C., \& Archieves, S. (2005). Genetic variability studies in maize (Zea mays L.) germplasm. Plant Archives, 5(1), 105-108.

Adhikari, B.N, Joshi, B.P., \& Shrestha, J. (2018). Genetic variability, heritability, genetic advance and correlation among yield and yield components of rice (Oryza sativa L.). Journal of Agriculture and Natural Resources, 1(1), 149-160.

DOI: https://doi.org/10.3126/janr.v1i1.22230

Adhikari, K. (2007). Maize in Nepal: Research Achievements (2004-2006) for food and feed security and livelihood improvement. Pp 1-6. In: D.B. Gurung. D.C. Paudel, G., K. C., S.R. Upadhya and B. B. Pokharel (Eds.). Proceedings of the 25 the National Summer crops Research Workshop on Maize Research and Production in Nepal, held on June 21-23, 2007 p.2.

Bartaula, S., Panthi, U., Timilsena, K., Acharya, S. S., \& Shrestha, J. (2019). Variability, heritability and genetic advance of maize (Zea mays L.) genotypes. Research in Agriculture Livestock and Fisheries, 6(2), 163-169.

DOI: https://doi.org/10.3329/ralf.v6i2.42962

Carangal, V.R., Ali, S.M., Koble, A.F., \& Rinke, E.H. (1971). Comparison of S1 with testcross evaluation for recurrent selection in maize. Crop Science, 11, 658-661. DOI: https://doi.org/10.2135/cropsci1971.0011183X001100050016x

Chaudhary, L., \& Prasad, B. (1968). Genetic variation and heritability of quantitative characters in Indian mustard (Brassica juncea). Indian Journal of Agricultural Science, $38,820-825$.

Falconer, D. S. (1996). Introduction to quantitative genetics. Harlow, England: Prentice Hall.

Ferdu, A., Demissew, K., \& Birhane, A. (2002). Major Insect Pests of Maize and their Management: A Review in: Nigussie, M., Tanner, D., \& Twumasi, A.S. (Eds.) 
Journal of Agriculture and Natural Resources (2020) 3(2): 127-139

ISSN: 2661-6270 (Print), ISSN: 2661-6289 (Online)

DOI: https://doi.org/10.3126/janr.v3i2.32491

Enhancing the Contribution of Maize to Food Security in Ethiopia. Proc. 2nd Nat. Maize Workshop, Addis Ababa Ethiopia, 12-16 Nov. 2001.

Ghimire, B., \& Timsina, D. (2015). Analysis of yield and yield attributing traits of maize genotypes in Chitwan, Nepal. World Journal of Agricultural Research, 3(5), 153-162. DOI: https://doi.org/10.12691/wjar-3-5-2

Gurung, D. B., Upadhyay, S. R., Pandey, B. R., Pokhrel, B. B., \& Kshetri, J. B. (2011). Hybrid maize seed production: A new initiative for reliable and sustainable hybrid maize seed supply in Nepal. Agriculture Development Journal, 8, 1-8.

Johnson, H., Robinson, H.F., \& Cornstock, R.E. (1955). Estimates of genetic and environmental variability in soybeans. Agronomy J, 47(3), 14-18. DOI: https://doi.org/10.2134/agronj1955.00021962004700070009x

Kapoor, R. \& Batra, C. (2015). Genetic variability and association studies in maize (Zea mays L.) 46 for green fodder yield and quality trait. Electronic Journal of Plant Breeding, 6(1), 233-240.

Khayatnezhad, M., Shahriari, R., Gholamin, R., Jamaati-E-Somarin, S., \& Zabihi-E Mahmoodabad, R. (2011). Correlation and Path Analysis Between Yield and Yield Components in Potato (Solanum tubersum L.). Middle-East Journal of Scientific Research, 7(1), 17-21. DOI: http://www.idosi.org/mejsr/mejsr7(1)11/4.pdf

Kumar, B.A., Gangappa, E., \& Savithramma, D.L. (2018) Genetic potential, variability, heritability and genetic advance of grain yield and its component traits in maize (Zea mays L.) inbreds. International Journal of Chemical Studies, 6(6), 2015-2018.

Manjunatha, B., Kumara, B. N., \& Jagadeesh, G. B. (2018). Performance Evaluation of Maize Hybrids (Zea mays L.). International Journal of Current Microbiology and Applied Sciences, 7(11), 1198-1203. DOI: https://doi.org/10.20546/ijcmas.2018.711.139

MoALD. (2020). Statistical Information on Nepalese Agriculture 2016/17. Singha Durbar, Kathmandu Nepal: Ministry of Agriculture and Development, Agri-Business Promotion and Statistics Division.

Nadagoud, V. (2008). Stability analysis of Maize (Zea mays L.) inbred lines introductions for yield parameters. M.Sc. thesis, University of Agricultural Science, College of Agriculture, Department of Genetics and Plant Breeding, Dharwad, 2008.

Ogunniyan, D. J., \& Olakojo, S. A. (2014). Genetic variation, heritability, genetic advance and agronomic character association of yellow elite inbred lines of maize (Zea mays L.). Nigerian Journal of Genetics, 28(2), 24-28.

DOI: https://doi.org/10.1016/j.nigjg.2015.06.005

Rahman, M., Hoque, A., Amir Hossain, M., \& Abdullah Al Bari, M. (2017). Variability and Traits Association Analyses in Maize (Zea mays L.) Genotypes. The Agriculturists, 15(2), 101-114. DOI: https://doi.org/10.3329/agric.v15i2.35473

Shrestha J., Yadav D.N., Amgain L.P., \& Sharma, J.P. (2018). Effects of nitrogen and plant density on maize (Zea mays L.) phenology and grain yield. Current Agriculture Research Journal, 6(2), 175-182. DOI: http://dx.doi.org/10.12944/CARJ.6.2.06

Singh, C. (2002). Modern techniques of raising field crops. Oxford and IBH Publishing Co. Pvt. Ltd., New Delhi. 573 p.

Sivasubramanian, S., \& Menon, M. (1973). Heterosis and inbreeding depression in rice. Advances in Agronomy, 47, 85-140.

Sridhar, M. (2017). Studies on Genetic Pameters for Yield and Yield Contributing Characters in Popcorn Genotypes (Zea mays var. Everta). International Journal of Pure \& Applied Bioscience, 5(4), 1525-1530. DOI: http://www.ijpab.com/vol5-iss4a216.php 
Tadesse, J., Leta, T., Techale, B., \& Lemi, B. (2018). Genetic variability, heritability and genetic advance of maize (Zea mays L.) inbred lines for yield and yield related traits in southwestern Ethiopia. Journal of Plant Breeding and Crop Science, 10(10), 281-289. DOI: https://doi.org/10.5897/JPBCS2018.0742

Taye, A. (2014). Genetic variability of yield and yield related traits in some maize inbred lines (Zea mays L.) developed for mid-altitude agro-ecology of Ethiopia. MSc thesis submitted to the collage of Natural and Computational Sciences, Department of Biology, School of Graduate Studies, Haramaya University.

Tripathi, M.P., Shrestha, J., \& Gurung, D.B. (2016). Performance evaluation of commercial maize hybrids across diverse Terai environments during the winter season in Nepal. Journal of Maize Research and Development, 2 (1), 1-12. DOI: http://dx.doi.org/10.3126/jmrd.v2i1.16210

Vashistha, A., Dixit, N. N., Dipika Sharma, S. K., \& Marker, S. (2013). Studies on heritability and genetic advance estimates in Maize genotypes. Biosci. Disc, 4(2), 165-168.

Wali, M., Arwailayah Freeman, T., Amponsah Adjei, E., Kollie, W. S., Pride, C. (2019). Genetic Variability and Divergence Studies in Maize (Zea mays L.). EC Agriculture $5(6)$.

Weber, C. R., \& Moorthy, B. R. (1952). Heritable and Nonheritable Relationships and Variability of Oil Content and Agronomic Characters in the F2 Generation of Soybean Crosses 1. Agronomy Journal, 44(4), 202-209. DOI: https://doi.org/10.2134/agronj1952.00021962004400040010x

Yusuf, M. (2010). Genetic variability and correlation in single cross hybrids of quality protein maize (zea mays 1.). Food Agric Nutrit Dev, 10(2), 2166-2175. 